\title{
THE INFLUENCE OF TECHNOLOGY AS A MEDIATOR ON THE RELATIONSHIP BETWEEN STUDENTS ANXIETY AND ENGAGEMENT
}

Tariq Mehmood Bhuttah ${ }^{1}$, Naeem Ullah ${ }^{2}$, Naseer Ahmad Shahid ${ }^{3}$, Samina Sarwat ${ }^{4 *}$

${ }^{1,2}$ Assistant Professor, Humanities and Social Sciences Department at Khwaja Fareed University of Engineering and Information Technology, RYK,64200 (Punjab), Pakistan; ${ }^{3}$ Senior Subject specialist, Government Higher Secondary School, Yazman, Bahawal Pur, Punjab, Pakistan; ${ }^{4 *}$ HOD, Assistant professor, Humanities and Social Sciences Department at Khwaja Fareed University of Engineering and Information Technology, RYK,64200 (Punjab), Pakistan. Email: ${ }^{1}$ tmbhuttah@kfueit.edu.pk, ${ }^{2}$ dr.naeemullah@kfueit.edu.pk, ${ }^{3}$ naseer.shahid@ymail.com, $4^{*}$ samina.sarwat@kfueit.edu.pk

Article History: Received on $31^{\text {st }}$ March 2021, Revised on $30^{\text {th }}$ May 2021, Published on $11^{\text {th }}$ June 2021

\begin{abstract}
The Purpose of the study: This study investigated the relationship between students' anxiety and students' engagement towards science in the presence of technology as a mediator.

Methodology: For this research, data were collected personally through three different questionnaires for Students' Academic Engagement, Anxiety towards Science, and Technology Attitude for Learning from the science students of $9^{\text {th }}$ and $10^{\text {th }}$ class at the secondary level. A total of 420 boys and girls participated in the study. The mediating analysis was performed in the Spss21 extension of Preacher and Hayes is used to analyse the data.

Main Findings: Findings showed that technology attitude for learning significantly mediates the relationship between anxiety towards science and students' academic engagement. The levels of students' academic engagement and technology attitude for learning are higher in male students as compared to female students, whereas anxiety towards science is higher in female students. Similarly, the level of anxiety towards science is significantly higher in $10^{\text {th }}$ class students as compared to students of class $9^{\text {th }}$. There is no significant difference in academic engagement and technology attitude for learning between $9^{\text {th }}$ and $10^{\text {th }}$ class students.
\end{abstract}

Application of the study: The previous literature has shown the significant negative effect of anxiety on student engagement. While the present research exposed that technology significantly mediates the relationship between anxiety and engagement. It is concluded that technical assistance for science subjects can reduce anxiety and enhance student engagement towards science.

Novelty/originality of the study: The integration of technology in the educational settings at the school level is not only crucial for students' better academic performance, but also it can assist the teacher by introducing new innovative ways of teaching.

Keywords: Technology, Students Anxiety, Student Engagement, Secondary Students, Science Subject, Academic Achievement.

\section{INTRODUCTION}

When student-teacher relationships are good (Martin et al., 2018), and students find the teacher to be professional, compassionate, invested, and successful, engagement is more likely to grow. Teachers who are confident in their ability to use technology are more likely to use it and be good at using it (Marcelo et al., 2019). Engagement can also be enhanced by providing a consistent, modified, flawless, and productive response (Martin et al., 2018). Since technology has become a core aspect of the student educational environment, the role it plays in influencing student interaction is a special area of concern (Henderson et al., 2017). Students' access to technology is a problem, and it can affect their motivation and previous experience (Zweekhorst et al., 2015).

Student engagement is the time spent on task, attention, classroom participation, attendance as well as ability to work independently as well as finishing it (Schoenfeld \& M, 2008; Searle et al., 2013). Better academic engagement results in excellent academic performance and academic skills. However, the constant mental absence hinders students to get fully engaged in academic activities (Wang et al., 2014). Student disengagement in science subjects is getting prominent both internationally and nationally.

Engagement is a multi-dimensional construct. The three widely accepted dimensions of student engagement are Cognitive, affective, and behavioral engagement (Fredricks et al., 2016). Cognitive engagement relates to selfregulation, the importance of schoolwork, the value of learning and personal goals and independence, psychological engagement or affective engagement relates to students relationships with teachers and other students as well as emotions, behavioral Engagement relates to attendance, class suspension, classroom, and extra-curricular participation, academic Engagement relates to time spent on task, courses credits, and homework completion, and Emotional engagement is about the emotions experienced by students such as anxiety, attitude, boredom, expectations, frustrations, fear, interest, involvement, and identification. 
Lack of student engagement in science classrooms has been a prominent reason for their bad performance (Shernoff et al., 2014; Uekawa et al., 2007). The teacher is considered as the most influencing factor for establishing the level of engagement in the classroom. In today's era of technology, the teacher is assisted by ICT, a teacher's familiarity, competence, and confidence with ICT are highly significant (Sharma \& Bhaumik, 2013). Students' satisfaction and socio-economic status of students also influence the level of student engagement (Mohamed \& Waheed, 2011). Further, curricula, way of teaching, lessons discontinuity, lack of connections between school and home, inappropriate standards, and educational policies also hinder students from being fully engaged in the science classrooms. Besides educational factors, psychological well-being also affects the students' engagement.

\section{The rationale of the study}

The purpose of this research is to expose the role of technology and how technology mediates the relationship between students' anxiety and engagement, especially towards science subjects. The rationale is to reconcile the role of technology that how it can bring a lot of motivation among the students of all the disciplines and increase students' academic achievement.

\section{Research Questions}

1. What is the correlation between students' academic engagement, anxiety towards science, and technology attitude for learning?

2. What is the difference in the levels of students' academic engagement, anxiety towards science, and technology attitude for learning between gender as well as a class?

\section{LITERATURE REVIEW}

Student disengagement in science subjects is getting prominent both internationally and nationally. During their studies (Oliver \& Jorre de St Jorre, 2018), acquiring twenty-first-century skills, the use of education technology in higher education has appealed to researchers' interest, for example, in the innovations that students find beneficial or unhelpful in their studies and trends of media use by non-traditional students (Dolch \& Zawacki-Richter, 2018).

Schools are in desperate need of seeking solutions to keep students engaged. By the Suitable use of technology in the classroom, students get motivation in all subjects, including math, social studies, and literacy. Students continue to see the inherent meaning of what they are learning as they use technology, which increases their curiosity and inspiration.

Furthermore, students can understand complex concepts by applying abstract theories to real-world conditions, resulting in increased competence. Teachers will use technology in the classroom to distinguish teaching, inspire pupils, and involve students at all ability levels by incorporating it into the classroom (James, 2017).

Many people believe that since technology is now ubiquitous in schools all over the world, it will help boost student involvement with science subjects, which would lead to improved learning performance and increased enrollment in science-related classes outside the obligatory school years. While studies (e.g. Beavis et al., 2015; Calder \& Campbell, 2016; Pierce \& Ball, 2009) show that the use of digital technologies improves student engagement, such standards are

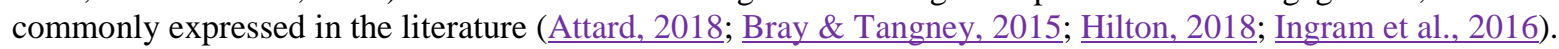

Using technology to enhance teaching and learning processes can be enhanced by using technology, it can boost student self-regulation and self-efficacy (Alioon \& Delialioğlu, 2017), it also increases course participation and commitment, and is expected to increase student engagement (Rashid \& Asghar, 2016).

To collect student work samples, offer guidance and feedback, and facilitate interaction outside of the classroom, technology also allows for innovative approaches (Attard, 2018; Calder \& Campbell, 2016; Hilton, 2018; Ingram et al., 2016). As a result, students now have new ways to transition from being customers to creators, which is a major departure from traditional classroom activities (

Furthermore, due to the rapid speed of technological advancement and rapid growth in its usage in educational environments and students' homes, the novelty element of their use in schools, which could have historically influenced participation, has likely diminished (Attard, 2015).

Thatswhy Students' attitude towards science (Javed et al., 2020), as well as anxiety towards science, is very prominent for affecting the engagement level of science students (Uluçinar Sağir, 2012). It is also a common disorder among children and adolescents (Mychailyszyn et al., 2012). The fear of failure in science subjects creates massive pressure on the student and thus causes anxiety. The students' bad experiences during science class, the anxious attitude of teachers towards science, gender, and racial differences also lead to anxiety for science subjects.

Studies have shown that high levels of science anxiety reduce the chances of getting succeeded in science subjects. It makes them worried and concerned for science, which results in poor performance of students (Topcu, 2010; Uluçinar Sağir, 2012) through a lack of understanding and difficulty in focus. Science anxiety makes students avoid science subjects and then science fields in the future (Mallow et al., 2010). 
Further, students with anxiety also face difficulties in making friends and classroom participation (Ryan \& Masia Warner, 2012). It makes students avoid engaging in academic activities (Mychailyszyn et al., 2011). Students with anxiety disorders are more likely to experience depression and have trouble concentrating. They still have a weaker sense of self-worth and academic achievement (McLoone et al., 2006).

Science students' anxiety also gets children into depression, suicidal thinking, or attempts, as well as substance abuse. It also affects students' concentration and ability to remember academic knowledge negatively (Segool et al., 2013; Weems et al., 2009). Anxiety can be prolonged, and if it remains untreated, it transforms into depression (Mychailyszyn et al., 2011). On the other hand, Students with less anxiety are excited and thus more inclined to pursue science in the future (Hassan, 2008).

To keep students engaged, there is a need to motivate them through persistent efforts that can genuinely engage students through learning activities (Curwin, 2010). The proper use of technology can bring a lot of motivation among the students of all the disciplines (Housand \& Housand, 2012). The current needs of the 21st century are no longer attainable in old learning environments (Gialamas \& Avgerinou, 2015). Technology has been considering as a solution for enhancing students' performance in urban schools because it can affect student engagement and learning significantly in the future.

However, in student engagement, considering the importance put on the potential for technology to play a formative role (Schindler et al. 2017). Student engagement is described as the amount of work and commitment students put forward within their learning environment, as measured by a variety of behavioral, cognitive, and affective factors over a spectrum. A variety of structural and internal forces, such as the dynamic interplay of interactions, learning experiences, and the learning environment, construct it. The more involved and motivated students are in their academic environment, the more likely they are to redirect that enthusiasm back into their studies, resulting in a variety of short and long-term results that can also enhance engagement (Bond et al., 2020, p. 3).

The students of the current generation are entirely engrossed in technology; thus, on the one hand, the implementation of technology in schools can accelerate their learning and academic achievement (Hassan \& Sajid, 2012). While on the other hand, the integration of digital in traditional schooling can also facilitate educators in teaching and learning (Adedoja \& Oluwadara, 2016; Wilson \& Boldeman, 2012). Technology usage in schools and classrooms not only has the power to engage students (Wilson \& Boldeman, 2012) but also can provide opportunities to develop valued skills and abilities. It can include problem-solving, creative thinking, collaborating as well as innovating (Cisco, 2008) with a rebooted educational setting, curriculum as well as teaching methods.

Although researchers have found anxiety as an opposing relationship with students' academic engagement, however, there is a need for more research to find the ways through which the negative impact of anxiety over academic engagement can be reduced. It is very essential to treat children facing anxiety issues at the school level. One of the methods is a school-based intervention which is very helpful in supporting adults having anxiety in various academic tasks.

There are several groups of studies relevant to the effect of technology on students' engagement and the effect of anxiety over student engagement. But studies with technology as a mediator are rare. There is a need to explore the influence of technology on the relationship between anxiety and students' engagement. This study intends to examine the relationship between students' anxiety and students' engagement at secondary school students, specifically for science subjects. This research mainly determines the role of technology between secondary students' engagement and anxiety towards science.

Technological interest can help them to create a strong foundation of Science ideas without having any anxiety. Learning with the help of technology not only makes students more confident in technology usage (Underwood, 2009) but also motivates and makes them attentive during the lesson. It can be summarized in a way that technology has the power to keep students engage during learning through creating motivation and interest (Chuang, 2014), reducing anxiety and thus increasing students' academic achievement. This study highlights the need for technology integration in science subjects to reduce the existing disengagement due to anxiety.

\section{Conceptual background}

Student engagement is built on academic, behavioral, cognitive, and psychological engagement (Appleton et al., 2006). Anxiety towards science subjects significantly affects the engagement level of science students (Uluçinar Sağir, 2012), and it is a common disorder among children and adolescents (Mychailyszyn et al., 2012).

The fear of failure in science subjects creates massive pressure on the student and thus causes anxiety, driven by students' bad experiences during a science lesson, the anxious attitude of teachers towards science, gender, and racial differences.

Studies have shown that high levels of science anxiety reduce the chances of getting succeeded in science subjects. It makes them worried and concerned for science, which results in poor performance of students (Topcu, 2010; Uluçinar 
Sağir, 2012) through a lack of understanding and difficulty in focus. Science anxiety makes students avoid science subjects and then science fields (Mallow et al., 2010).

Technological interest can help them to create a strong foundation of Science ideas without having any anxiety. Learning with the help of technology not only makes students more confident in technology usage (Underwood, 2009) but also motivates and makes them attentive during the lesson (Balanskat, 2006). It can be summarized in a way that technology has the power to keep students engage during learning through creating motivation and interest (Chuang, 2014), reducing anxiety and thus increasing students' academic achievement. This study highlights the need for technology integration in science subjects to reduce the existing disengagement due to anxiety.

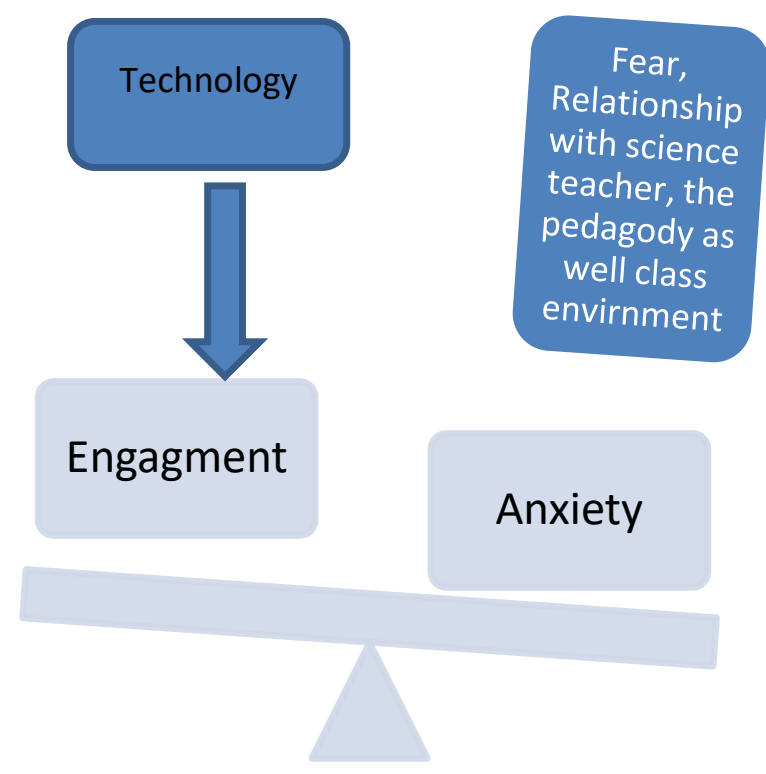

Figure 1: Conceptual background

\section{Hypothesis}

$\mathrm{H}_{1}$ : Students' academic engagement and anxiety towards science are positively correlated with technology attitude for learning.

$\mathrm{H}_{2}$ : There is a gender and class-based difference among students' academic engagement, anxiety towards science, and technology attitude for learning.

\section{METHODOLOGY}

This study tried to investigate the mediating effect of technology on the relationship between anxiety and engagement for science students. The present study employed the quantitative method. To determine the role of technology in mediating the relationship between students' attitudes toward science and maximum academic engagement, the questionnaires were adapted from various studies. For selecting schools and students, we used basic random sampling.

Besides mediation analysis, the Correlation Analysis Independent Samples t-test was also calculated.

\section{Sample/Participants}

Total 828 government schools exist in Lodhran, with 487 of them were for female students. In public sector schools, the district has an enrolment of 146,345 students. The population of the study is science students of secondary schools in Lodhran city. Random sampling was done to choose students. A total of 420 boys and girls participated in the study. The sample of this current study only focused on government schools, and it has the potential to cover the general attitude of science students in the Pakistani educational scenario. The participants of this study are only science students of secondary school, studying in the 9th and 10th, including males and females.

\section{Instruments}

Three different questionnaires were adopted for the analysis. These variables were Students' Academic Engagement, Anxiety towards Science, and Technology Attitude for Learning. Where students' anxiety towards science was chosen as independent, student academic engagement as a dependent, and students' attitude towards technology was taken as mediator. The data was collected personally through the survey method from the science students of 9 th and $10^{\text {th }}$ at the secondary level. The mediating analysis was performed in the Spss21 extension of Preacher and Hayes. The details of the three variables are given below: 


\section{Students' academic engagement scale}

In this analysis, the Students' academic engagement scale was taken as a dependent variable. The data for this variable was collected through a questionnaire based on Utrecht Work Engagement Scale-Student (Schaufeli et al., 2002). The UWES-S is an academic engagement scale consisting of 14 items. This questionnaire covers passion, dedication, and concentration. The response for each item of the survey was gathered according to 5-point Likert-type scales as Always, Frequently, Usually, Rarely, and Never.

\section{Anxiety towards science scale}

Students' anxiety towards the science scale is an independent variable of this study. The data for this variable were gathered through a questionnaire adopted from (Uluçinar Sağir, 2012)'s measure of anxiety. The response of this questionnaire was based on a Likert style, having strongly agreed, agree, I am not sure, disagree, and strongly disagree for all the selected 27 items of this variable.

\section{Technology attitude scale for learning}

The technology attitude scale for learning is a mediator in this study. This scale has three parts, measures access, perceptions, and learning with the help of technology. Items1-11 in the first section of this questionnaire pertains to the students' extent of access to various forms of technology. No access, restricted access, and maximum access to technology were assessed on a 3-point Likert scale. While the items 12-19 belong to the second part of the questionnaire, which measures students' perceptions of learning with Technology. The third part of the questionnaire consisted of eight items 20-28 that determine the level of students' learning with the help of technology. All the items of the second and third parts were collected based on a 5-point Likert scale containing strongly disagree, disagree, neutral, agree, strongly agree (Chenoby, 2014).

\section{Data Analysis Method}

The data was collected personally through the survey method from the science students of 9 th and $10^{\text {th }}$ at the secondary level. The mediating analysis was performed in the Spss21 extension of Preacher and Hayes. Three variables were Students' Academic Engagement, Anxiety towards Science, and Technology Attitude for Learning.

\section{RESULTS}

This research aimed to see whether technology acts as a mediator between student anxiety and academic achievement. The information collected was then organized into tables and figures to see how Implementation truly mediates the relationship between student academic achievement and anxiety.

\section{Correlation Analysis}

Table 1: Descriptive statistics and correlations for Students Academic Engagement, Anxiety towards Science and Technology Attitude for Learning

\begin{tabular}{llll}
\hline Scales & Mean \pm SD 1 & 2 & 3 \\
\hline Students' Academic Engagement & $44.70 \pm 4.131$ & - & - \\
\hline Anxiety towards Science & $80.61 \pm 7.10-.454^{* *}$ & 1 & - \\
\hline Technology Attitude for Learning $69.19 \pm 6.45 .859^{* * *}$ & $-.475^{* *} 1$ \\
\hline **. Correlation is significant at the 0.01 level (2-tailed). & \\
\hline *. Correlation is significant at the 0.05 level (2-tailed). \\
\hline c. List-wise N=420
\end{tabular}

Table 1 displays descriptive statistics findings as well as an association between students' academic engagement, science anxiety, and technology attitude for learning. From the results, we can conclude that students' academic engagement and anxiety towards science are significantly negatively correlated with each other while significantly positively correlated with technology attitude for learning. Similarly, anxiety towards science is a significantly negatively correlated technology attitude for learning.

\section{Mediation Analysis}

The Regression was run to investigate if technology could mediate the effect of anxiety on students' academic engagement. The mediating analysis was performed on the Spss21 extension of Preacher and Hayes. The data was gathered irrespective of gender and class level. All the participants are purely science students of the $9^{\text {th }}$ and $10^{\text {th }}$ classes. Technology attitude towards learning as a mediator, students' academic engagement as a dependent, and students' anxiety towards science as an independent variable. The results of mediating analysis in figure 2 below are showing that technology attitude for learning is a significant mediator between anxiety towards science and students' academic engagement where

$\mathrm{TAL}=$ Technology attitude for learning

ATS = Anxiety towards science 
$\mathrm{SAE}=$ Students' ${ }^{\prime}$ academic engagement

\section{Independent Samples t-test}

Students' Academic Engagement, Students' Anxiety towards research, and Students' Technology Attitude towards Learning were all compared using separate studies t-tests at the gender and class levels.

Table 2: Gender-Based Differences among Students' Academic Engagement, Anxiety towards Science and Technology Attitude for Learning

\begin{tabular}{lllllll}
\hline & \multicolumn{7}{l}{ Male } & \multicolumn{7}{l}{ Female } & \\
\cline { 2 - 7 } & $(\mathrm{n}=179)$ & $\mathrm{n}=171)$ & & \\
\cline { 2 - 7 } Variables & $\mathrm{M}$ & $\mathrm{SD}$ & $\mathrm{M}$ & $\mathrm{SD}$ & $\mathrm{t}$ & $\mathrm{p}$ \\
\hline Students' Academic Engagement & 45.162 & 4.12 & 44.211 & 4.09 & 2.167 & $.016^{*}$ \\
\hline Anxiety towards Science & 78.899 & 6.46 & 82.392 & 7.30 & -4.742 & $.000^{* * *}$ \\
\hline Technology Attitude for Learning & 70.022 & 6.67 & 68.328 & 6.11 & 2.475 & $.007^{* *}$ \\
\hline
\end{tabular}

Table 3: Class-Based Differences among Students' Academic Engagement, Anxiety towards Science and Technology Attitude for Learning

\begin{tabular}{lcccccc}
\hline & $9^{\text {th }}$ Class & \multicolumn{7}{c}{$10^{\text {th }}$ Class } \\
\cline { 2 - 7 } & $(\mathrm{n}=177)$ & \multicolumn{1}{c}{$(\mathrm{n}=173)$} & & \\
\cline { 2 - 7 } Variables & $\mathrm{M}$ & $\mathrm{SD}$ & $\mathrm{M}$ & $\mathrm{SD}$ & $\mathrm{t}$ & $\mathrm{p}$ \\
\hline Students' Academic Engagement & 44.559 & 4.61 & 44.838 & 3.58 & -0.631 & .264 \\
\hline Anxiety towards Science & 79.797 & 7.27 & 81.434 & 6.83 & -2.134 & $.016^{*}$ \\
\hline Technology Attitude for Learning & 69.277 & 7.32 & 69.110 & 5.44 & 0.242 & .405 \\
\hline
\end{tabular}

Table 2 and Table 3 depict the results of independent samples t-test tests to compare the differences in the levels of students' academic engagement, anxiety towards science, and technology attitude for learning between gender as well as class. The results revealed that male students have higher levels of academic interest and technology attitude for learning than female students, whereas female students have higher levels of science anxiety than male students. Similarly, the level of anxiety towards science is significantly higher in the students of class $10^{\text {th }}$ as compared to students of class $9^{\text {th }}$ while students' academic engagement and technology attitude for learning are not significantly different between students of class $9^{\text {th }}$ and 10th.

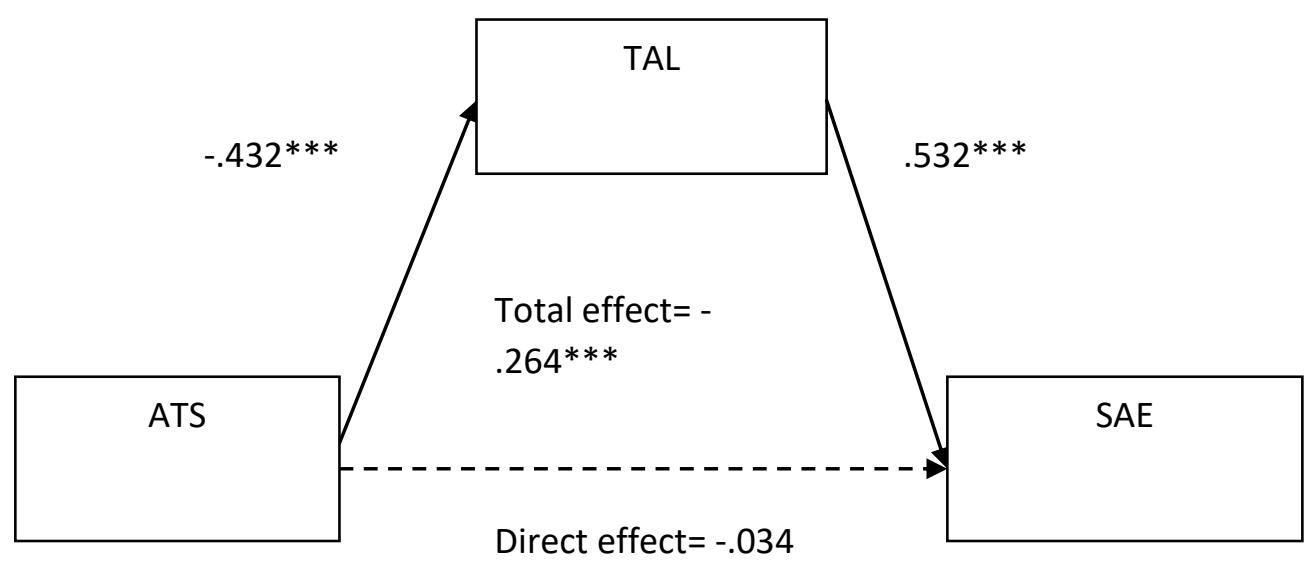

Figure 2: Mediating analysis, Students' Academic Engagement as an outcome, anxiety towards science as Independent variable and Technology Attitude for Learning as Mediator

\section{Findings}

The previous literature has shown the significant negative effect of anxiety on student engagement. The present research exposed that technology significantly mediates the relationship between anxiety and engagement.

The finding has shown that students' academic engagement and anxiety towards science are significantly negatively correlated with each other while significantly positively correlated with technology attitude for learning. Similarly, anxiety towards science is a significantly negatively correlated technology attitude for learning. While anxiety towards science is higher in female students as compared to male students. Similarly, the level of anxiety towards science is significantly higher in the students of class $10^{\text {th }}$ as compared to students of class $9^{\text {th }}$ while students' academic engagement and technology attitude for learning are not significantly different between students of class $9^{\text {th }}$ and 10 th. 
The findings of the study also shown that technology is a significant mediator for science students and thus can enhance their engagement in science by reducing science-related anxiety. It also exposed that technology significantly mediates the relationship between anxiety and engagement.

\section{CONCLUSION}

The purpose of this study was to emphasize the importance of integration of technology in science learning so that the level of engagement in science subjects by reducing the anxiety towards science. The previous literature has shown the significant negative effect of anxiety on student engagement. Similarly, the studies have also revealed the importance of technology in student engagement. The present research exposed that technology significantly mediates the relationship between anxiety and engagement. The current quantitative analysis based on science students helped to know the better insight of students' opinions. All three questionnaires also tried to capture the three different yet highly relevant aspects of science students as anxiety, engagement, and technology.

The integration of technology in the educational settings at the school level is not only crucial for students' better academic performance, but also it can assist the teacher by introducing new innovative ways of teaching. Therefore there should be a massive investment in educational technology for educational achievement. As a developing country, the education system of Pakistan is not as technologically developed, especially at the school level. The specified education budget does not allow technological facilitation at the school level. However, the students have access to various technological devices at their homes on a personal level. While students in Pakistan have optimistic feelings about science in comparison to the world's deteriorating trend in science, there is simply a need to comply with Minimum Development Goals so that students can bring a massive change in the field of science, which is pivotal for Pakistan's development.

\section{LIMITATIONS}

While the results include an informative viewpoint on the dynamic interrelationships between the frameworks of student participation, self-directed learning, academic success, and technology use, there are several limitations.

- First of all, the class from which we were collecting data was limited to 9th and 10th-grade students only. Related research of students from other year levels, such as primary school students, who do not usually switch from lesson to lesson or class to class as high school students do, may be conducted in the future. Much of them were biased due to the lack of confidence which's why did not answer correctly.

- Secondly, we don't have access to art students or small group students. And we were allowed only to focus on the research that is between 2015 to onwards.

- Thirdly, to student engagement and learning, the role of faculty and organizational dimensions is considered much crucial, but we have no faculty cooperation as well. We don't know exactly that how many teachers there were because we don't include them.

- Lastly, the time was limited, so we could not cover all the institutes of the district.

\section{ACKNOWLEDGEMENT}

The study was self-supported by the Faculty of Humanities and Social Sciences at Khwaja Fareed University of Engineering and Information Technology, Rahim Yar Khan 64200.

\section{AUTHORS CONTRIBUTION}

Tariq Mehmood Bhuttah is the first author conceptual work and review, while Naeem Ullah and Naseer Ahmad Shahid are working on Data analysis, Samina Sarwat is the Corresponding author to this manuscript.

\section{REFERENCES}

1. Adedoja, G., \& Oluwadara, A. (2016). Influence of Age and Training on Planning Instruction Using Mobiles Phones by Pre-service Social Studies Teachers. Wireless and Mobile Technologies, 3(1), 1-6. http://pubs.sciepub.com/wmt/3/1/1

2. Alioon, Y., \& Delialioğlu, Ö. (2017). The effect of authentic m-learning activities on student engagement and motivation. British Journal of Educational Technology. 32, 121. https://doi.org/10.1111/bjet.12559

3. Appleton, J. J., Christenson, S. L., Kim, D., \& Reschly, A. L. (2006). Measuring cognitive and psychological engagement: Validation of the Student Engagement Instrument. Journal of School Psychology, 44(5), 427-445. https://doi.org/10.1016/j.jsp.2006.04.002

4. Attard, C., (2015). Introducing iPads into primary mathematics classrooms : teachers' experiences and pedagogies. In: Integrating Touch-Enabled and Mobile Devices into Contemporary Mathematics Education. pp. 193-213. https://doi.org/10.4018/978-1-4666-8714-1.ch009

5. Attard, C. (2018). Mobile technologies in the primary mathematics classroom: engaging or not?. In: Mathematics Education in the Digital Era. Using Mobile Technologies in the Teaching and Learning of Mathematics. pp. 51-65. https://doi.org/10.1007/978-3-319-90179-4_4 
6. Balanskat, A., Roger Blamire and Stella Kefala. (2006). The Impact Report: A Review of Studies of ICT Impact on Schools in Europe. Corpus ID: 5258214. http://portaldoprofessor.mec.gov.br/stor age/materiais/0000012853.pdf

7. Boaler, Jo. (2015). Mathematical Mindsets: Unleashing Students' Potential through Creative Math, Inspiring Messages and Innovative Teaching. John Wiley \& Sons.

8. Bond, M., Buntins, K., Bedenlier, S., Zawacki-Richter, O., \& Kerres, M. (2020). Mapping research in student engagement and educational technology in higher education: A systematic evidence map. International Journal of Educational Technology in Higher Education, 17(1), 1-30. https://doi.org/10.1186/s41239-019-0176-8

9. Bray, A., Tangney, B. (2015). Enhancing student engagement through the affordances of mobile technology: a 21 st century learning perspective on Realistic Mathematics Education. Math. Educ. Res. J., 28 (1), 173-197 https://doi.org/10.1007/s13394-015-0158-7.

10. Chenoby, H. (2014). The role of ICT in student engagement in learning mathematics in a preparatory university program, Retrieved from Melbourne Australia. https://vuir.vu.edu.au/25852/1/Helen\%20 Chenoby.pdf

11. Chuang, Y.-T. (2014). Increasing learning motivation and student engagement through the technologysupported learning environment. Creative Education, 5(23), 1969. https://doi.org/10.4236/ce.2014.523221

12. Cisco. (2008). Equipping every learner for the 21st Century. Executive Summary. Retrieved from https://www.cisco.com/c/dam/en_us/about/citizenship/socio-economic/docs/Global_Ed_Exec_Summary.pdf

13. Curwin, R. (2010). Meeting students where they live: motivation in urban schools. Alexandria, VA: ASCD.

14. Dolch, C., \& Zawacki-Richter, O. (2018). Are students getting used to learning technology? Changing media usage patterns of traditional and non-traditional students in higher education. Research in Learning Technology, 26. https://doi.org/10.25304/rlt.v26.2038

15. Fredricks, JA. Filsecker, M., \& Lawson, MA. (2016). Student engagement, context and adjustment: Addressing definitional, measurement, and methodological issues. Learning and Instruction, 43, 1-4. https://doi.org/10.101 6/j.learninstruc.2016.02.002

16. Gialamas, S. \& Avgerinou, M.D. (2015). Aristeia Leadership: A Catalyst for the i2Flex Methodology. Educational Policy Analysis and Strategic Research, 10(1), 13-23.

17. Hassan, G. (2008). Attitudes toward science among Australian tertiary and secondary school students. Research in Science \& Technological Education 26: 129-147. Research in Science \& Technological Education, 26, 129147. https://doi.org/10.1080/02635140802034762

18. Hassan, T., \& Sajid, A. (2012). ICTs in Learning in Pakistan. International Journal of Evaluation and Research in Education (IJERE), 1. https://doi.org/10.11591/ijere.v1i2.1244

19. Henderson, M., Selwyn, N., \& Aston, R. (2017). What works and why? Student perceptions of 'useful' digital technology in university teaching and learning. Studies in Higher Education, 42(8), 1567-1579. https://doi.or $\mathrm{g} / 10.1080 / 03075079.2015 .1007946$

20. Hilton, A. (2018). Engaging primary school students in mathematics: can iPads make a difference? Int. J. Sci. Math. Educ., 16 (1), 145-165. https://doi.org/10.1007/s10763-016-9771-5

21. Housand, B. C., \& Housand, A. M. (2012). The role of technology in gifted students' motivation. Psychology in the Schools, 49(7), 706-715. https://doi.org/10.1002/pits.21629

22. Ingram, N., Williamson-Leadley, S., Pratt, K., 2016. Showing and telling: using tablet technology to engage students in mathematics. Math. Educ. Res. J., 28 (1), 123-147. https://doi.org/10.1007/s13394-015-0162-y

23. James, F. (2017). "The Effects of Technology On Student Motivation And Engagement In Classroom-Based Learning". All Theses and Dissertations. 121. http://dune.une.edu/theses/121

24. Javed, S., Wenlan, Z., Ghaffari, A. S., \& Bhuttah, T. M. (2020). The mediating role of technology between students' attitudes and engagement towards science: a quantitative study of students' perception. International Transaction Journal of Engineering, Management, \& Applied Sciences \& Technologies, 11(3), 11A03H, 1-13.

25. Mallow, J., Kastrup, H., Bryant, F. B., Hislop, N., Shefner, R., \& Udo, M. (2010). Science Anxiety, Science Attitudes, and Gender: Interviews from a Binational Study. Journal of Science Education and Technology, 19(4), 356-369. https://doi.org/10.1007/s10956-010-9205-Z

26. Marcelo, C., \& Yot-Domínguez, C. (2019). From chalk to keyboard in higher education classrooms: changes and coherence when integrating technological knowledge into pedagogical content knowledge. Journal of Further and Higher Education, 43(7), 975-988. https://doi.org/10.1080/0309877X.2018.1429584

27. Martin, F., \& Bolliger, DU. (2018). Engagement matters: Student perceptions on the importance of engagement strategies in the online learning environment. Online Learning, 22(1), 205-222. https://doi.org/10.24 059/olj.v22i1.1092

28. McLoone, J., Hudson, J., \& Rapee, R. (2006). Treating Anxiety Disorders in a School Setting. Education \& Treatment of Children, 29, 219-242.

29. Mohamed, L., \& Waheed, H. (2011). Secondary Students' Attitude towards Mathematics in a Selected School of Maldives. 1(15), 277-281.

30. Mychailyszyn, M., Beidas, R., Wolk, C., Edmunds, J., Podell, J., Cohen, J., \& Kendall, P. (2011). Assessing and Treating Child Anxiety in Schools. Psychology in the Schools, 48, 223-232. https://doi.org/10.1 002/pits. 20548 
31. Mychailyszyn, M., Brodman, D., Read, K., \& Kendall, P. (2012). Cognitive-Behavioral School-Based Interventions for Anxious and Depressed Youth: A Meta-Analysis of Outcomes. Clinical Psychology Science and Practice, 19, 129-153. https://doi.org/10.1111/j.1468-2850.2012.01279.x

32. Oliver, B., \& Jorre de St Jorre, T. (2018). Graduate attributes for 2020 and beyond: Recommendations for Australian higher education providers. Higher Education Research \& Development, 37(4), 821-836. https://doi.org/10.1080/07294360.2018.1446415

33. Rashid, T., \& Asghar, H. M. (2016). Technology use, self-directed learning, student engagement and academic performance: Examining the interrelations. Computers in Human Behavior, 63, 604-612. https://doi.org/10.1016/j.chb.2016.05.084

34. Ryan, J., \& Masia Warner, C. (2012). Treating Adolescents with Social Anxiety Disorder in Schools. Child and adolescent psychiatric clinics of North America, 21, 105-118, ix. https://doi.org/10.1016/j.chc.2011.08.011

35. Schindler, LA., Burkholder, GJ., Morad, OA., \& Marsh, C. (2017). Computer-based technology and student engagement: a critical review of the literature. International Journal of Educational Technology in Higher Education, 14(1), 25. https://doi.org/10.1186/s41239-017-0063-0

36. Schoenfeld, N., \& M, J. (2008). Identification and Treatment of Anxiety in Students with Emotional or Behavioral Disorders: A Review of the Literature. Education and Treatment of Children, 31, 583-610. https://doi.org/10.1353/etc.0.0034

37. Searle, A., Miller-Lewis, L., Sawyer, M., \& Baghurst, P. (2013). Predictors of Children's Kindergarten Classroom Engagement: Preschool Adult-Child Relationships, Self-Concept, and Hyperactivity/Inattention. Early Education \& Development, 24, 1112-1136. https://doi.org/10.1080/10409289.2013.764223

38. Segool, N. K., Carlson, J. S., Goforth, A. N., von der Embse, N., \& Barterian, J. A. (2013). Heightened test anxiety among young children: elementary school students' anxious responses to high-stakes testing. Psychology in the Schools, 50(5), 489-499. https://doi.org/10.1002/pits.21689

39. Sharma, B. R., \& Bhaumik, P. K. (2013). Student Engagement and Its Predictors: An Exploratory Study in an Indian Business School. Global Business Review, 14(1), 25-42. https://doi.org/10.1177/0972150912466364

40. Shernoff, D. J., Csikszentmihalyi, M., Schneider, B., \& Shernoff, E. S. (2014). Student Engagement in High School Classrooms from the Perspective of Flow Theory. In Applications of Flow in Human Development and Education: The Collected Works of Mihaly Csikszentmihalyi (pp. 475-494). Dordrecht: Springer Netherlands. https://doi.org/10.1007/978-94-017-9094-9_24

41. Topcu, M. (2010). Development of Attitudes towards Socioscientific Issues Scale for undergraduate students. Evaluation \& Research in Education, 23, 51-67. https://doi.org/10.1080/09500791003628187

42. Uekawa, K., Borman, K., \& Lee, R. (2007). Student Engagement in U.S. Urban High School Mathematics and Science Classrooms: Findings on Social Organization, Race, and Ethnicity. The Urban Review, 39(1), 1-43. https://doi.org/10.1007/s11256-006-0039-1

43. Uluçinar Sağir, Ş. (2012). The primary school students' attitude and anxiety towards science. Journal of Baltic Science Education, 11, 127-140.

44. Underwood, J. D. M. (2009). The impact of digital technology: a review of the evidence of the impact of digital technologies on formal education. Retrieved from the UK: Becta.

45. Wang, Z., Bergin, C., \& Bergin, D. (2014). Measuring Engagement in Fourth to Twelfth Grade Classrooms: The Classroom Engagement Inventory. School psychology quarterly: the official journal of the Division of School Psychology, American Psychological Association, 29, 517-535. https://doi.org/10.1037/spq0000050

46. Weems, C. F., Taylor, L. K., Costa, N. M., Marks, A. B., Romano, D. M., Verrett, S. L., \& Brown, D. M. (2009). Effect of a school-based test anxiety intervention in ethnic minority youth exposed to Hurricane Katrina. Journal of Applied Developmental Psychology, 30(3), 218-226. https://doi.org/10.1016/j.ap pdev.2008.11.005

47. Wilson, K. L., \& Boldeman, S. U. (2012). Exploring ICT Integration as a Tool to Engage Young People at a Flexible Learning Centre. Journal of Science Education and Technology, 21(6), 661-668. https://doi.org/10.1 007/s10956-011-9355-7

48. Zweekhorst, MBM., \& Maas, J. (2015). ICT in higher education: Students perceive increased engagement. Journal of Applied Research in Higher Education, 7(1), 2-18. https://doi.org/10.1108/JARHE-02-2014-0022 